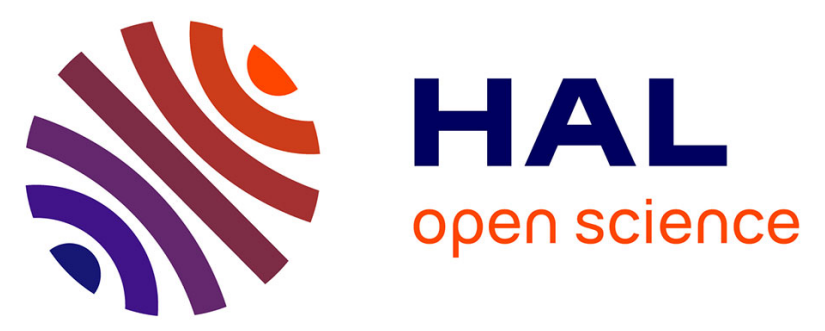

\title{
A simple approach for controlled deposition of Prussian blue analogue nanoparticles on a functionalised plasmonic gold surface
}

Giang Ngo, Gautier Félix, Jérôme Long, Luca Costa, Oscar Saavedra V., Pierre-Emmanuel Milhiet, Jean-Marie Devoisselle, Yannick Guari, Joulia Larionova, Joel Chopineau

\section{To cite this version:}

Giang Ngo, Gautier Félix, Jérôme Long, Luca Costa, Oscar Saavedra V., et al.. A simple approach for controlled deposition of Prussian blue analogue nanoparticles on a functionalised plasmonic gold surface. New Journal of Chemistry, 2019, 43 (9), pp.3660-3664. 10.1039/C9NJ00251K . hal-02065154

\author{
HAL Id: hal-02065154 \\ https://hal.science/hal-02065154
}

Submitted on 24 Jul 2019

HAL is a multi-disciplinary open access archive for the deposit and dissemination of scientific research documents, whether they are published or not. The documents may come from teaching and research institutions in France or abroad, or from public or private research centers.
L'archive ouverte pluridisciplinaire HAL, est destinée au dépôt et à la diffusion de documents scientifiques de niveau recherche, publiés ou non, émanant des établissements d'enseignement et de recherche français ou étrangers, des laboratoires publics ou privés. 


\title{
A simple approach for controlled deposition of Prussian Blue Analogues nanoparticles on a functionalised plasmonic gold surface ${ }^{\dagger}$
}

\author{
Giang Ngo, ${ }^{a}$ Gautier Félix, ${ }^{* a}$ Jérôme Long, ${ }^{a}$ Luca Costa, ${ }^{b}$ Oscar Saavedra V., ${ }^{b}$ Pierre-Emmanuel Milhiet,${ }^{b}$ Jean-Marie \\ Devoisselle, ${ }^{a}$ Yannick Guari, ${ }^{a}$ Joulia Larionova, ${ }^{a}$ Joël Chopineau*a,c \\ a Institut Charles Gerhardt Montpellier (ICGM), Univ Montpellier, ENSCM, CNRS, Montpellier, France. \\ ${ }^{b}$ Centre de Biochimie Structurale (CBS), CNRS, INSERM, Univ Montpellier, France \\ c Université de Nimes, Rue Georges Salan 30000 Nîmes, France
}

E-mail: joel.chopineau@enscm.fr, gautier.felix@umontpellier.fr

New J. Chem., 2019, 43, 3660, DOI: 10.1039/c9nj00251k

\begin{abstract}
We report here a simple and efficient approach for the controlled deposition of a monolayer of Prussian blue analogue nanoparticles on a gold surface functionalised with amino groups and their characterisation by surface plasmon resonance spectroscopy and atomic force microscopy combined with theoretical modeling.
\end{abstract}

Prussian blue analogues (PBA) are coordination cyano-bridged networks having the general formula $\mathrm{A}_{1-\mathrm{x}} \mathrm{M}\left[\mathrm{M}^{\prime}(\mathrm{CN})_{6}\right]_{1-\mathrm{x} / 3} \square_{\mathrm{z}}$ (A is a monovalent cation, $\mathrm{M}$ and $\mathrm{M}^{\prime}$ are transition metal ions, $\square$ is the cyanometallate vacancies), in which $\mathrm{M}$ and $\mathrm{M}$ ' are connected through cyano-bridges leading to a three-dimensional face-centered cubic open-framework. The large workable combinations of transition metal ions lead to a wide family of PBA with different interesting physico-chemical properties, including magnetic behaviour, ${ }^{1-3}$ electronic phase-change phenomena, ${ }^{4-6}$ photo-switching phenomenon, ${ }^{7-10}$ gas and ion absorption/hydrogen storage, ${ }^{11}$ and negative thermal expansion. ${ }^{12,13}$ Compare to their bulk counterparts, PBA nanoparticles (NPs) exhibit unique size and shape dependent features, ${ }^{14}$ such as for instance optical, ${ }^{15}$ magnetic, ${ }^{16,17}$ and elastic ${ }^{18,19}$ properties, which may find potential applications in many fields ${ }^{20}$ including electrode devices, ${ }^{21}$ electronics, optics, biology ${ }^{22}$ and medicine. ${ }^{23,24}$ Considering that several of these applications require the NPs on a planar surface, the controlled deposition or patterning of PBA NPs on a surface is an important challenge. ${ }^{25}$ In this line of thought, three different approaches may be cited. ${ }^{26}$ The first one consists in the electrochemical deposition of Prussian blue and PBA thin films on platinum, ${ }^{27}$ glassy carbon and indium-doped tin oxide, ${ }^{28}$ or gold single crystals. ${ }^{29}$ Another strategy involving a sequential layer-by-layer deposition on a polyethylene terephthalate polymer solid surface (Melinex), conducting to a series of magnetic and photo-magnetic PBA thin films, has been developed by D. Talham's group. ${ }^{30-32}$ This consecutive approach has been extended to the design of mono and multi-layered paramagnetic and ferromagnetic PBA films directly grown on a functionalized $\mathrm{Si}(100)$ surface $^{33}$ or on a quartz or indium tin oxide surface. ${ }^{34}$ Secondly, nanostructured PBA on a gold surface has been obtained by A.

$\dagger$ Electronic Supplementary Information (ESI) available on NJC website
Bleuzen and coll. by sequential nanopatterning. ${ }^{35}$ The third approach includes the homogeneous deposition of already formed PB nanoparticles on a positively charged indium tin oxide conductive glass and gold surface, ${ }^{36}$ functionalized with amine $\mathrm{Au}$ electrodes ${ }^{37}$ or $\mathrm{SiO}_{2}{ }^{38}$ surfaces.

Gold surfaces present several advantages for the deposition of metal-organic frameworks ${ }^{39}$ and particularly of PBA NP layers and their investigation: (i) they may be easily functionalised by a self-assembled monolayer (SAM) with a variety of ligands able to anchor NPs, ${ }^{40-43}$ (ii) these SAMs can control the deposition and dispersion of nano-objects. ${ }^{44,45}$ In this work, we propose a simple method to implement and optimise the controlled deposition of a monolayer of well-dispersed $\mathrm{K}^{+} / \mathrm{Ni}^{2+} /\left[\mathrm{Fe}(\mathrm{CN})_{6}\right]^{3-}$ PBA NPs on a large $\left(1 \mathrm{~cm}^{2}\right)$ gold surface functionalised with a SAM of aminoethanethiol. A particular emphasis is given to the detailed characterisation of the obtained PBA@Au materials by using SPR measurements and AFM imaging both assisted by theoretical modelling. This combined approach complements also the original method for the measurement of the refractive index of PBA nanoparticles.

$\mathrm{K}^{+} / \mathrm{Ni}^{2+} /\left[\mathrm{Fe}(\mathrm{CN})_{6}\right]^{3-}$ PBA NPs were synthesised by the controlled addition of the respective molecular precursors, $\mathrm{NiCl}_{2} \cdot 6 \mathrm{H}_{2} \mathrm{O}$ and $\mathrm{K}_{3}\left[\mathrm{Fe}(\mathrm{CN})_{6}\right]$, , using the synthetic strategy we previously reported for other PBA to give $\mathrm{K}_{0.04} \mathrm{Ni}\left[\mathrm{Fe}(\mathrm{CN})_{6}\right]_{0.62} \cdot{ }^{18,23}$ The IR spectrum (Fig. S1a, ESI $\dagger$ ) shows the typical stretching vibrations at 2166 and $2100 \mathrm{~cm}^{-1}$ corresponding to the $\mathrm{Fe}^{\mathrm{III}}{ }_{-} \mathrm{CN}-\mathrm{Ni}^{\mathrm{II}}$ and $\mathrm{Fe}^{\mathrm{II}}{ }_{-} \mathrm{CN}-\mathrm{Ni}^{\mathrm{II}}$ linkages of the PBA cyano-bridged network, respectively. ${ }^{46}$ The transmission electronic microscopy (TEM) images show the presence of PBA NPs with a well-defined cubic shape with a mean length edge equal to $35 \pm 3 \mathrm{~nm}$ (Fig. S1b and c, ESI $\dagger$ ). A negative zeta potential of $-23 \mathrm{mV}$ measured for the particles indicates the presence of the $\left[\mathrm{Fe}(\mathrm{CN})_{6}\right]^{3-}$ moiety on the NPs' surface, which contributes to their stabilization and good dispersion in water. ${ }^{47}$ As a simple way to anchor the NPs on a gold surface, a thin layer of aminoethanethiol of about $5 \AA$ (see ESI $\dagger$ ) has been used. ${ }^{40,48}$ In our experimental conditions, $\mathrm{pH}>7$; the surface amine functions are therefore able to coordinate the $\mathrm{Ni}^{2+}$ ions located at the surface of the PBA nanoparticles but the presence of the electrostatic interactions between the nanoparticles and the surface cannot be excluded.

The deposition of NPs suspended in water at different concentrations $(0.04,0.08,0.16,0.31,0.62,1.50$ and 2.50 
(a) SPR measurement before the deposition NPs deposit in SPR cell
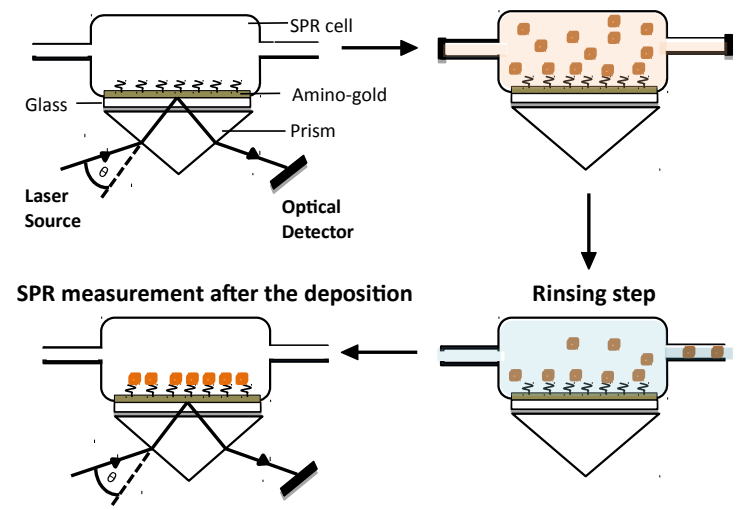

(b)

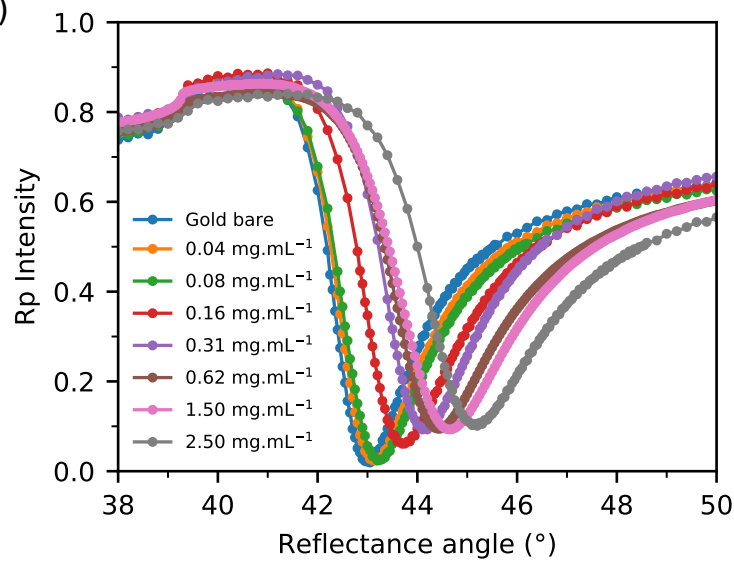

Fig. 1 (a) Scheme of NP deposition on the amino-gold surface in an SPR cell; (b) normalized intensity of the total internal reflection of PBA NPs on the gold aminated surface for the different NP concentrations in suspension with a p-polarisation of light $\left(R_{p}\right)$ as a function of the internal reflection angle (SPR recordings). Lines are guide for the eyes.

mg.mL ${ }^{-1}$ ) on the amino-gold surface was conducted and monitored using a home-made SPR setup. ${ }^{49}$ For this purpose, the slides were deposited on an optical BK-7 right angle prism to obtain the Kretschmann configuration (a total internal reflection of light in p-polarisation). To get an optical continuity, a refractive index matching oil was used between the gold slide and the optical prism. Then, an SPR chamber (1 mL) was mounted on the amino-gold surface (Fig. 1a). The determination of the resonance angle (minimum of SPR curve) of the amino-gold surface was performed in air using the total internal reflectivity configuration with incident angles ranging between $38.00^{\circ}$ and $50.00^{\circ}$. The intensity of reflected light decreases sharply to almost zero for a reflectance angle of $43.10^{\circ}$; this value was set as the reference resonance angle. Then, for NP deposition, the SPR chamber was filled with $1 \mathrm{~mL}$ of the NP suspension. After 7 hours, the cell was thoroughly rinsed with $25 \mathrm{~mL}$ of ultrapure water, to be sure that all unbound NPs were removed. Nitrogen gas was flowed gently inside the chamber for 3 minutes to dry the surface. SPR measurements of the NPs deposited on the amino-gold surfaces were performed in air. Fig. 1b shows the SPR spectra for samples containing a different amount of NPs. When the concentration of NPs in the initial suspension increases, a shift of the resonance angle from $43.22^{\circ}$ to $45.17^{\circ}$ was observed. The right-shift of the resonance angle is usually linked with two major phenomena, a change in the refractive index of the NPs and the amount of NPs deposited on
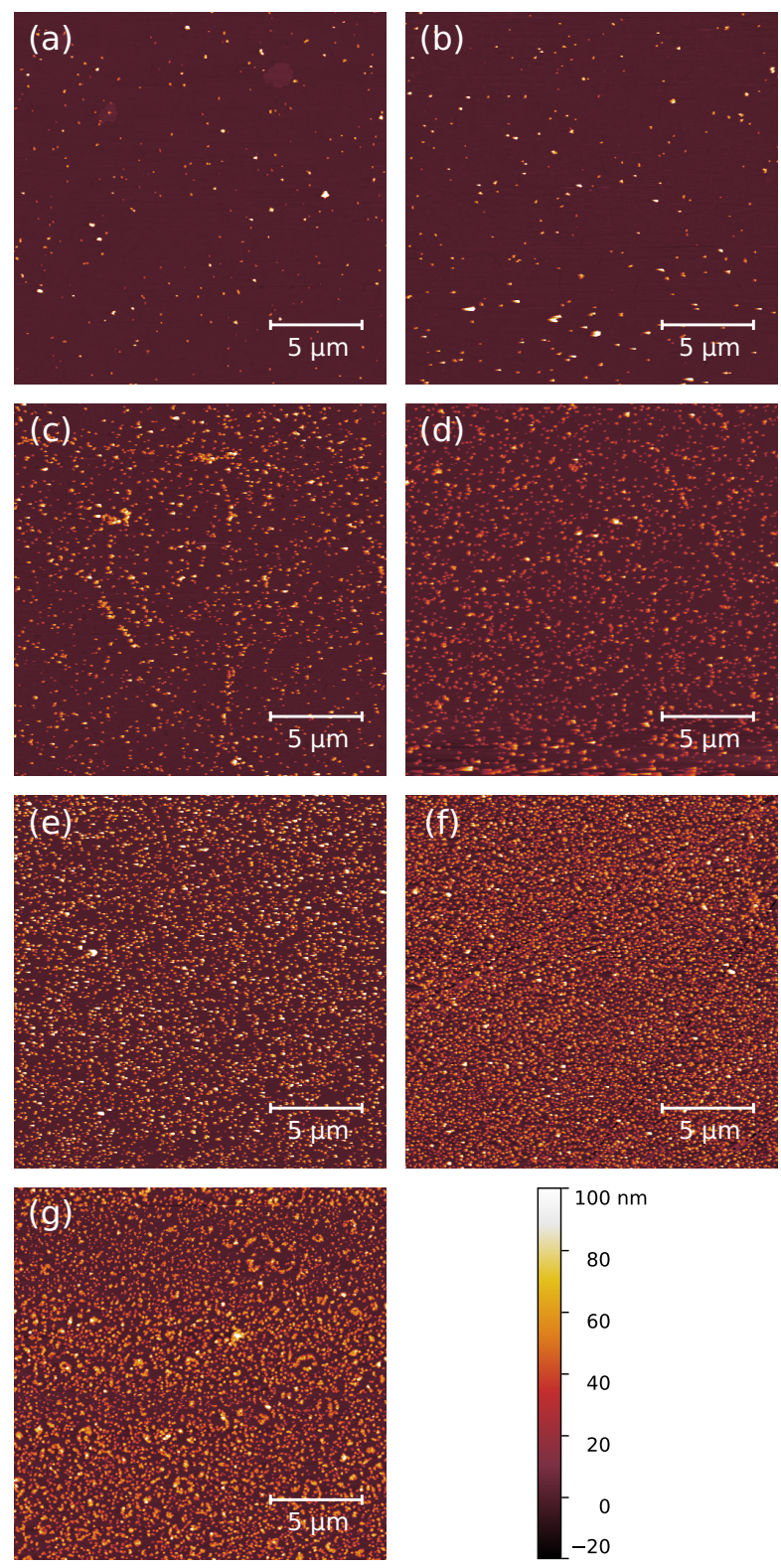

Fig. 2 AFM images with scale bar $20 \times 20 \mu \mathrm{m}$ of the PBA NPs deposited on the amino-gold surface with different initial concentrations: (a) $0.04 \mathrm{mg} \cdot \mathrm{mL}^{-1}$; (b) $0.08 \mathrm{mg} \cdot \mathrm{mL}^{-1}$; (c) $0.16 \mathrm{mg} \cdot \mathrm{mL}^{-1}$; (d) 0.31 $\mathrm{mg} \cdot \mathrm{mL}^{-1}$; (e) $0.62 \mathrm{mg} \cdot \mathrm{mL}^{-1}$; (f) $1.50 \mathrm{mg} \cdot \mathrm{mL}^{-1}$; (g) $2.50 \mathrm{mg} \cdot \mathrm{mL}^{-1}$.

the amino-gold surface. As the NP refractive index is assumed to be the same for all samples, the difference in the observed resonance angles is a consequence of an augmentation of the amount of NPs deposited on the amino-gold surface. However, the SPR measurements provide an overall optical thickness of the thin deposit on the amino surface, but no information is given concerning the organization of NPs on the surface. The IR spectra of the PBA NPs deposited on the Au surface present also two peaks ( 2166 and $2100 \mathrm{~cm}^{-1}$ ), confirming that the PBA structure has been preserved after deposition (see Fig. S2a, ESI†).

Atomic force microscopy (AFM) was therefore used to image the NP-amino-gold surface at the nanometre scale. Fig. 2 displays AFM images, performed in amplitude modulation AFM mode (AM-AFM) in ambient conditions, ${ }^{50,51}$ for the 7 samples with different amounts of NPs. Several AFM images were taken at different areas for $5 \times 5 \mu \mathrm{m}^{2}$ and $20 \times 20 \mu \mathrm{m}^{2}$. They show 


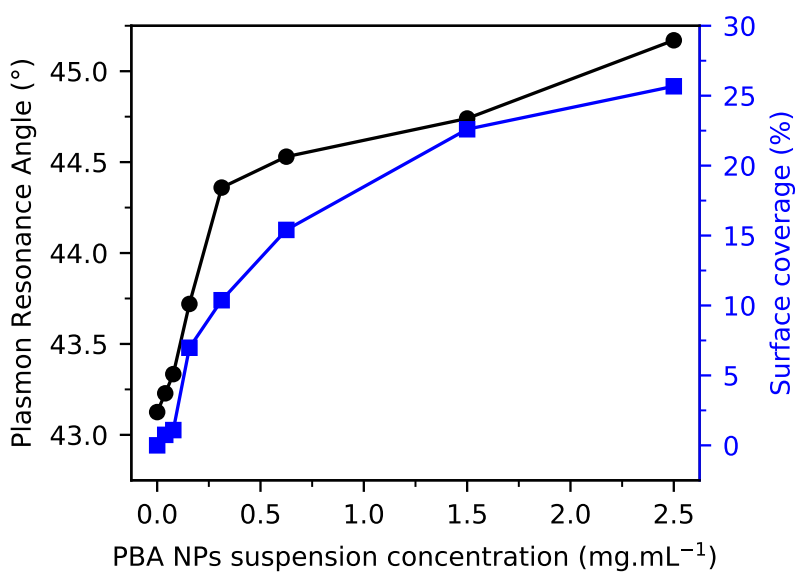

Fig. 3 Surface coverage (blue squares) and plasmon resonance angles (black circles) as a function of the NP concentration. Lines are a guide for the eyes.

a homogeneous distribution of the NPs on the surface. Note that the average height shown in Fig. 2 is less than twice the height of a nanoparticle (the mean height of NPs measured in all AFM image is $40 \pm 10 \mathrm{~nm}$, see Fig. S3c, ESI†). We can conclude that the NP deposition on the amino-gold surface can be approximated as a discrete coverage of individual PBA NPs. A zoomed-in view of the surface dispersion and roughness $(1 \mathrm{~nm}$ for the substrate roughness) for the sample with a suspension concentration of $0.16 \mathrm{mg} \cdot \mathrm{mL}^{-1}$ (Fig. 2c) shows that each point in the AFM image represents one nano-object (See Fig S3a, b). For each topographic AFM image, we used the Gwyddion software $^{52}$ and the threshold method to estimate the coverage of the surface by PBA NPs. According to the initial concentration of NPs, the surface coverage increased from $0.8 \%$ to $25.7 \%$. The SPR resonance angle values and the surface coverage as a function of the concentration of PBA NP suspension are exposed in Fig. 3. Both curves, which seem to have correlated behaviour, show that there are two different regimes in the coverage process: at low concentration, the evolution of the surface coverage is linear as a function of the NP concentration and then, the surface coverage increases moderately and tends to saturate. As it was discussed previously, the surface of NPs is negatively charged, which tends to isolate them during the deposition process, which besides the presence of amino groups at the surface can explain the homogeneous deposition of the NPs. 45

The experimental SPR resonance angle was compared to that of the simulated curves obtained by the generalised Rouard method applied to an absorbing thin-film stack. ${ }^{53}$ The model allows simulating the reflectance and the transmission of a multi-layer optical system, where each layer was assumed as perfectly flat and homogeneous. The parameters of the model are the thickness of each layer and their complex refractive index (the real part is the refractive index and the imaginary part is the optical absorption). It is important to note that the optical absorption of gold in the visible wavelength domain is strongly linked to the plasmonic phenomenon. The Maxwell-Garnett equation ${ }^{54,55}$ can be used to calculate an effective refractive index $n_{\text {eff }}$ of the NPs-air mixture (See ESI $\dagger$ ), and then used as the refractive index of the NP layer in the generalized Rouard method. Fig. 4a shows the result of simulations of the SPR spectra obtained for the same surface coverage values as those (a)

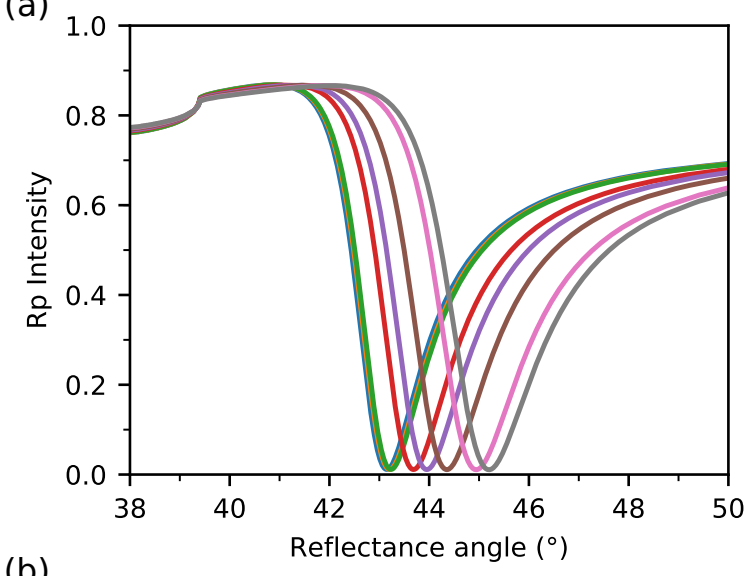

(b)

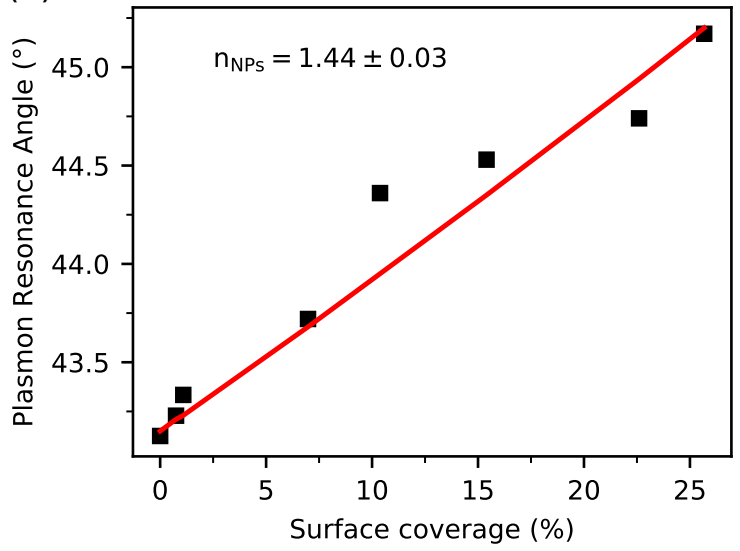

Fig. 4 (a) Plasmon curves calculated using the Rouard method with surface coverage similar to the experiment; (b) plasmonic resonance angles as a function of the surface coverage of NPs on the amino-gold surface. The black squares represent the experimental points and the red curve is the fitting obtained with modelization.

determined from the AFM experimental data (see Fig. 3). The resonance angles obtained from the experimental SPR curves were fitted using the minima of the simulated SPR curves, by the non-linear least square method coupled with a Monte-Carlo random walk with a large number of steps. For each step, a random refractive index has been chosen and kept only if the least square error was smaller. In Fig. 4b the minima of the simulated curves (red line) and the shift of resonance plasmon angles of the experimental curves (black squares) were plotted as a function of the surface coverage of NPs on the gold surface. The results of the fit (Fig. 4b) and the simulated plasmon curves of Fig. 4a gave a refractive index for the NPs of $1.44 \pm 0.03$ at a wavelength of $632.8 \mathrm{~nm}$. In parallel, we have extracted the refractive index of the PBA NPs from a refractometry measurement of a NPs-water mixture (see ESI $\uparrow$ for details). The result gave a value of 1.44 at a wavelength of 589 $\mathrm{nm}$, which is in good agreement with the SPR measurement.

As reported in Fig. 1b and Fig. 2, the right shift of the plasmon curve minima observed in Fig. 4a is induced by rising of the surface coverage of NPs on the gold surface. Note that the intensity of the SPR experimental curves has not been taken into account to extract the refractive index of NPs because it does not influence the SPR resonance angle and then the extracted refractive index. Also, the variation of the former can be induced by the absorption of NPs and the scattering produced by the roughness of the NP surface (see Fig. S4 and S5, ESI†). 
In summary, we report a simple and efficient method for controlled chemical deposition of the PBA NPs on a gold aminated surface. The cubic $\mathrm{K}^{+} / \mathrm{Ni}^{2+} /\left[\mathrm{Fe}(\mathrm{CN})_{6}\right]^{3-} \mathrm{NPs}$ of $35 \mathrm{~nm}$ were anchored to the surface mainly via coordination bonds between the $\mathrm{Ni}^{2+}$ ions situated on the surface of the NPs and those available on the gold surface amino functions. The control of the NP amount on the surface is achieved by the variation of the initial concentration of NPs in the aqueous suspensions, giving in all cases a homogeneous distribution of the NPs on the overall $\mathrm{Au}$ surface, as confirmed by SPR measurements and AFM imaging. The SPR data were fitted using the generalized Rouard method and the Maxwell-Garnett equation providing the determination of a refractive index for PBA NPs. This approach for NP deposition can be easily extended to other inorganic NPs with interesting physicochemical properties, which opens the way for various applications.

\section{Conflicts of interest}

There are no conflicts to declare.

\section{Acknowledgements}

The CBS is a member of the France-BioImaging (FBI) and the French Infrastructure for Integrated Structural Biology (FRISBI), 2 national infrastructures supported by the French National Research Agency (ANR-10-INBS-04-01 and ANR-10INBS-05, respectively). Oscar Saavedra acknowledges funding from the European Union's Horizon 2020 research and innovation program under the Marie Sklodowska-Curie grant agreement No. 721874 (SPM2.0).

\section{Notes and references}

1 W. R. Entley and G. S. Girolami, Science, 1995, 268, 397-400. DOI: 10.1126/science.268.5209.397.

2 S. Ferlay, T. Mallah, R. Ouahès, P. Veillet and M. Verdaguer, Nature, 1995, 378, 701-703. DOI: $10.1038 / 378701 \mathrm{a} 0$.

3 M. Verdaguer, A. Bleuzen, V. Marvaud, J. Vaissermann, M. Seuleiman, C. Desplanches, A. Scuiller, C. Train, R. Garde, G. Gelly, C. Lomenech, I. Rosenman, P. Veillet, C. Cartier and F. Villain, Coord. Chem. Rev., 1999, 190-192, 10231047. DOI: 10.1016/S0010-8545(99)00156-3.

4 N. Shimamoto, S.-i. Ohkoshi, O. Sato and K. Hashimoto, Inorg. Chem., 2002, 41, 678-684. DOI: 10.1021/ic010915u.

5 W. Kosaka, K. Nomura, K. Hashimoto and S.-i. Ohkoshi, J. Am. Chem. Soc., 2005, 127, 8590-8591. DOI: 10.1021/ja0501181.

6 T. Mahfoud, G. Molnár, S. Bonhommeau, S. Cobo, L. Salmon, P. Demont, H. Tokoro, S.-I. Ohkoshi, K. Boukheddaden and A. Bousseksou, J. Am. Chem. Soc., 2009, 131, 15049-15054. DOI: 10.1021/ja9055855.

7 O. Sato, T. Iyoda, A. Fujishima and K. Hashimoto, Science, 1996, 272, 704 705. DOI: $10.1126 /$ science.272.5262.704.

8 V. Escax, A. Bleuzen, J. P. Itié, P. Munsch, F. Varret and M. Verdaguer, J. Phys. Chem. B, 2003, 107, 4763-4767. DOI: 10.1021/jp0340313.

9 S.-i. Ohkoshi, H. Tokoro and K. Hashimoto, Coord. Chem. Rev., 2005, 249, 1830-1840. DOI: 10.1016/j.ccr.2004.11.015

10 H. Tokoro, T. Matsuda, K. Hashimoto and S.-i. Ohkoshi, J App. Phys., 2005, 97, 10M508. DOI: 10.1063/1.1850831.

11 S. S. Kaye and J. R. Long, J. Am. Chem. Soc., 2005, 127, 6506-6507. DOI: 10.1021/ja051168t.

12 K. W. Chapman, P. J. Chupas and C. J. Kepert, J. Am. Chem. Soc., 2006, 128, 7009-7014. DOI: 10.1021/ja060916r.

13 A. L. Goodwin, K. W. Chapman and C. J. Kepert, J. Am. Chem. Soc., 2005, 127, 17980-17981. DOI: 10.1021/ja056460f.

14 L. Catala and T. Mallah, Coord. Chem. Rev., 2017, 346, 32-61. DOI: 10.1016/j.ccr.2017.04.005.

15 D. Brinzei, L. Catala, C. Mathonière, W. Wernsdorfer, A. Gloter, O. Stephan and T. Mallah, J. Am. Chem. Soc., 2007, 129, 3778-3779. DOI: 10.1021/ja068451s.

16 L. Catala, T. Gacoin, J.-P. Boilot, É. Rivière, C. Paulsen, E. Lhotel and T. Mallah, Adv. Mater., 2003, 15, 826-829. DOI: 10.1002/adma.200304696.

17 W. Kosaka, M. Tozawa, K. Hashimoto and S.-i. Ohkoshi, Inorg. Chem. Commun., 2006, 9, 920-922. DOI: 10.1016/j.inoche.2006.05.032.

18 G. Félix, W. Nicolazzi, L. Salmon, G. Molnár, M. Perrier, G. Maurin, J. Larionova, J. Long, Y. Guari and A. Bousseksou, Phys. Rev. Lett., 2013, 110 235701. DOI: 10.1103/PhysRevLett.110.235701.

19 G. Félix, M. Mikolasek, H. J. Shepherd, J. Long, J. Larionova, Y. Guari, J.-P.
Itié, A. I. Chumakov, W. Nicolazzi, G. Molnár and A. Bousseksou, Eur. J. Inorg. Chem., 2018, 2018, 443-448. DOI: 10.1002/ejic.201700796.

20 M. Wang, L. Yang, B. Hu, J. Liu, L. He, Q. Jia, Y. Song and Z. Zhang, Biosens. Bioelectron., 2018, 113, 16 - 24. DOI: https://doi.org/10.1016/j.bios.2018.04.050.

21 L. He, B. Cui, B. Hu, J. Liu, K. Tian, M. Wang, Y. Song, S. Fang, Z. Zhang and Q. Jia, ACS Appl. Energy Mater., 2018, 1, 3915-3928. DOI: 10.1021/acsaem.8b00663.

22 N. Zhou, L. Yang, B. Hu, Y. Song, L. He, W. Chen, Z. Zhang, Z. Liu and S. Lu, Anal. Chem., 2018, 90, 13624-13631. DOI: 10.1021/acs.analchem.8b03850.

23 G. Maurin-Pasturel, E. Rascol, M. Busson, S. Sevestre, J. Lai-Kee-Him, P. Bron, J. Long, J. Chopineau, J.-M. Devoisselle, Y. Guari and J. Larionova, Inorg. Chem. Front., 2017, 4, 1737-1741. DOI: 10.1039/C7QI00321H.

24 G. Dacarro, A. Taglietti and P. Pallavicini, Molecules, 2018, 23, 1414. DOI: 10.3390/molecules23061414.

25 D. P. Goronzy, M. Ebrahimi, F. Rosei, Arramel, Y. Fang, S. De Feyter, S. L. Tait, C. Wang, P. H. Beton, A. T. S. Wee, P. S. Weiss and D. F. Perepichka, ACS Nano, 2018, 12, 7445-7481. DOI: 10.1021/acsnano.8b03513.

26 D. R. Talham and M. W. Meisel, Chem. Soc. Rev., 2011, 40, 3356-3365. DOI: 10.1039/C1CS15015D.

27 O. Sato, Y. Einaga, T. Iyoda, A. Fujishima and K. Hashimoto, J. Phys. Chem. $B, 1997,101,3903-3905$. DOI: 10.1021/jp9701451.

28 W. E. Buschmann, S. C. Paulson, C. M. Wynn, M. A. Girtu, A. J. Epstein, H. S. White and J. S. Miller, Chem. Mater., 1998, 10, 1386-1395. DOI: 10.1021/cm970773v.

29 S. Nakanishi, G. Lu, H. M. Kothari, E. W. Bohannan and J. A. Switzer, J. Am. Chem. Soc., 2003, 125, 14998-14999. DOI: 10.1021/ja0381151.

30 F. A. Frye, D. M. Pajerowski, S. M. Lane, N. E. Anderson, J.-H. Park, M. W. Meisel and D. R. Talham, Polyhedron, 2007, 26, 2281-2286. DOI: 10.1016/j.poly.2006.11.043.

31 F. A. Frye, D. M. Pajerowski, J.-H. Park, M. W. Meisel and D. R. Talham, Chem. Mater., 2008, 20, 5706-5713. DOI: 10.1021/cm800576s.

32 D. M. Pajerowski, J. E. Gardner, D. R. Talham and M. W. Meisel, New J. Chem., 2011, 35, 1320-1326. DOI: 10.1039/C0NJ00841A.

33 S. Tricard, C. Costa-Coquelard, S. Mazerat, E. Rivière, V. Huc, C. David, F. Miserque, P. Jegou, S. Palacin and T. Mallah, Dalton Transactions, 2012, 41, 4445-4450. DOI: 10.1039/C2DT11943A.

34 M. Pyrasch and B. Tieke, Langmuir, 2001, 17, 7706-7709. DOI: 10.1021/la0104424.

35 V. Trannoy, M. Faustini, D. Grosso, F. Brisset, P. Beaunier, E. Rivière, M. Putero and A. Bleuzen, Nanoscale, 2017, 9, 5234-5243. DOI: 10.1039/C7NR00024C.

36 D. Jiang, L. Sun, T. Liu and W. Wang, Anal. Chem., 2017, 89, 11641-11647. DOI: 10.1021/acs.analchem.7b03061.

37 N. Zhu, X. Hao, J. Ulstrup and Q. Chi, ACS Catal., 2016, 6, 2728-2738. DOI: 10.1021/acscatal.6b00411.

38 G. Dacarro, P. Grisoli, M. Borzenkov, C. Milanese, E. Fratini, G. Ferraro, A. Taglietti and P. Pallavicini, Supramol. Chem., 2017, 29, 823-833. DOI: 10.1080/10610278.2017.1372582

39 L. He, F. Duan, Y. Song, C. Guo, H. Zhao, J.-Y. Tian, Z. Zhang, C.-S. Liu, X. Zhang, P. Wang, M. Du and S.-M. Fang, 2D Mater., 2017, 4, 025098. DOI: 10.1088/2053-1583/aa6fc6.

40 M. D. Porter, T. B. Bright, D. L. Allara and C. E. D. Chidsey, J. Am. Chem. Soc., 1987, 109, 3559-3568. DOI: 10.1021/ja00246a011.

41 C. D. Bain, E. B. Troughton, Y. T. Tao, J. Evall, G. M. Whitesides and R. G. Nuzzo, J. Am. Chem. Soc., 1989, 111, 321-335. DOI: 10.1021/ja00183a049.

42 W. Knoll, Annu. Rev. Phys. Chem., 1998, 49, 569-638. DOI: 10.1146/annurev.physchem.49.1.569.

43 Y. Xue, X. Li, H. Li and W. Zhang, Nat. Commun., 2014, 5, 4348. DOI: $10.1038 /$ ncomms5348.

44 I. U. Vakarelski, C. E. McNamee and K. Higashitani, Colloids Surf. A, 2007, 295, 16-20. DOI: 10.1016/j.colsurfa.2006.08.021.

45 C. Grunewald, M. Schmudde, C. N. Noufele, C. Graf and T. Risse, Anal. Chem., 2015, 87, 10642-10649. DOI: 10.1021/acs.analchem.5b03572.

46 Y. Guari, J. Larionova, K. Molvinger, B. Folch and C. Guérin, Chem. Commun., 2006, 2613-2615. DOI: 10.1039/b602460b.

47 S.-J. Wang, C.-S. Chen and L.-C. Chen, Sci. Technol. Adv. Mater., 2016, 14, 044405. DOI: 10.1088/1468-6996/14/4/044405.

48 C. Rossi, J. Homand, C. Bauche, H. Hamdi, D. Ladant and J. Chopineau, Biochemistry, 2003, 42, 15273-15283. DOI: 10.1021/bi035336a.

49 R. Veneziano, C. Rossi, A. Chenal, J.-M. Devoisselle, D. Ladant and J. Chopineau, Proc. Natl. Acad. Sci. U.S.A., 2013, 110, 20473-20478. DOI: 10.1073/pnas.1312975110.

50 R. García, Amplitude Modulation Atomic Force Microscopy: GARCIA:AMPLIT.MODULATION O-BK, Wiley-VCH Verlag GmbH \& Co. KGaA, Weinheim, Germany, 2010. DOI: 10.1002/9783527632183.

51 G. Marinaro, M. Burghammer, L. Costa, T. Dane, F. De Angelis, E. Di Fabrizio and C. Riekel, ACS Appl. Mater. Interfaces, 2015, 7, 12373-12379. DOI: 10.1021/am507509z.

52 D. Nečas and P. Klapetek, Open Physics, 2011, 10, 181-188. DOI: 10.2478/s11534-011-0096-2.

53 P. Lecaruyer, E. Maillart, M. Canva and J. Rolland, Appl. Opt., 2006, 45, 84198423. DOI: $10.1364 / \mathrm{AO} .45 .008419$

54 J. C. M. Garnett, Phil. Trans. R. Soc. Lond. A, 1904, 203, 385-420. DOI: 10.1098/rsta.1904.0024.

55 R. Ruppin, Opt. Commun., 2000, 182, 273-279. DOI: 10.1016/S00304018(00)00825-7. 